\title{
A new carnivorous shallow-water sponge from McMurdo Sound, Antarctica (Porifera, Poecilosclerida)
}

\author{
Rob W. M. van Soest • Bill J. Baker
}

Received: 18 August 2010 /Revised: 4 October 2010 /Accepted: 12 November 2010 / Published online: 1 December 2010

(C) The Author(s) 2010. This article is published with open access at Springerlink.com

\begin{abstract}
A new shallow-water representative of the carnviorous sponge genus Asbestopluma is described from the southernmost Antarctic region of McMurdo Sound. Asbestopluma (Asbestopluma) vaceleti $\mathrm{n} . \mathrm{sp}$. is a white, thin, sparingly branched sponge fringed by filaments along its entire length, with a slight thickening at the top of the branches. It was collected at $30 \mathrm{~m}$ depth by SCUBA divers from under densely populated overhangs of rocky substrata. The new species stands out among Antarctic Asbestopluma by the possession of forceps microscleres, a feature shared with several species from Arctic-Boreal waters (bathyal to deep-sea) and one from the Kermadec Trench (deep sea), but not previously reported from Antarctic species. A unique trait of the new species distinguishing it from all forceps-bearing Asbestopluma is a second category of reduced anisochelae. The new species is most similar to A. hypogea, a shallow-water cave species from the Mediterranean, which differs in having a smooth stalk and a filament-bearing ovoid body. A comparison is made with descriptions of Antarctic Asbestopluma species and all species possessing forceps microscleres.
\end{abstract}

Keywords Antarctica Carnivorous sponge .

Asbestopluma $\cdot$ New species

R. W. M. van Soest $(\square)$

Zoölogisch Museum Amsterdam,

Netherlands Centre for Biodiversity,

P.O. Box 94766, 1090 GT, Amsterdam, the Netherlands

e-mail: R.W.M.vanSoest@uva.nl

\section{B. J. Baker}

Department of Chemistry, University of South Florida,

Tampa, FL 33620, USA

e-mail: bjbaker@usf.edu

\section{Introduction}

Carnivorous sponges, family Cladorhizidae, are unique in the phylum Porifera in possessing a combination of skeletal and organic tissue properties allowing them to catch small prey animals such as copepods and cladocerans (Vacelet and Boury-Esnault 1995). With the exception of the genus Chondrocladia Thomson (1873), the sponges of this family lack an aquiferous system. The overwhelming majority of carnivorous sponges occur in deep sea soft bottom habitats, and their deviating feeding strategy and accompanying physical features are explained as an adaptation to paucity of filter feeding biomass in oligotrophic deep sea habitats. The carnivorous feeding strategy was first detected in Asbestopluma hypogea Vacelet and Boury-Esnault (1996), which in contrast to most other cladorhizids lives in a shallow-water rocky habitat (caves near Marseille). Nevertheless, this habitat is considered similarly oligotroph and considered a displaced deep sea environment allowing the colonization of deep sea specialist sponges. Recently, SCUBA exploration of Antarctic rocky habitats near McMurdo Sound, yielded approximately 45 species of sponges (B. Baker, personsal communication). Among these shallow-water sponges, surprisingly, a species of Asbestopluma was found growing in a richly populated semi-open cave habitat at $30 \mathrm{~m}$ depth. The genus Asbestopluma counts 31 species (Van Soest et al. 2008), including two species of the subgenus Helophloeina Topsent (1929). Comparison with descriptions of Asbestopluma species from Antarctic waters and elsewhere led to the conclusion that the species is new to science. It is the purpose of this study to describe and name this species. The presumed oligotrophy cannot be confirmed for the habitat of this species which calls for additional considerations concerning the carnivorous feeding strategy. 


\section{Materials and methods}

Sponge material studied here is deposited in the collections of the Zoological Museum of the University of Amsterdam (ZMA). For microscopic examination, a fragment of the sponge was dissolved in concentrated nitric acid and the residue was rinsed several times in distilled water. The resultant spicule suspension was mounted on SEM stubs for examination under a JEOL Scanning Electron Microscope and on several glass slides for light microscopic examination. In addition, thick sections were mounted on glass slides for the study of the skeleton structure. Digital images of the spicules were assembled on a black background and aligned and cleaned up using Adobe Photoshop CS3. Thick sections were photographed using a Nikon photomicroscope. Spicule sizes (smallest-average-largest) were determined from 25 light microscopy measurements for each spicule category.

\section{Systematic Descriptions}

\section{Class Demospongiae}

Order Poecilosclerida

Suborder Mycalina

Family Cladorhizidae

Genus Asbestopluma Topsent, 1901

Subgenus Asbestopluma Topsent, 1901 sensu Vacelet, 2006 Asbestopluma (Asbestopluma) vaceleti n.sp.

Figs. 1, 2, 3
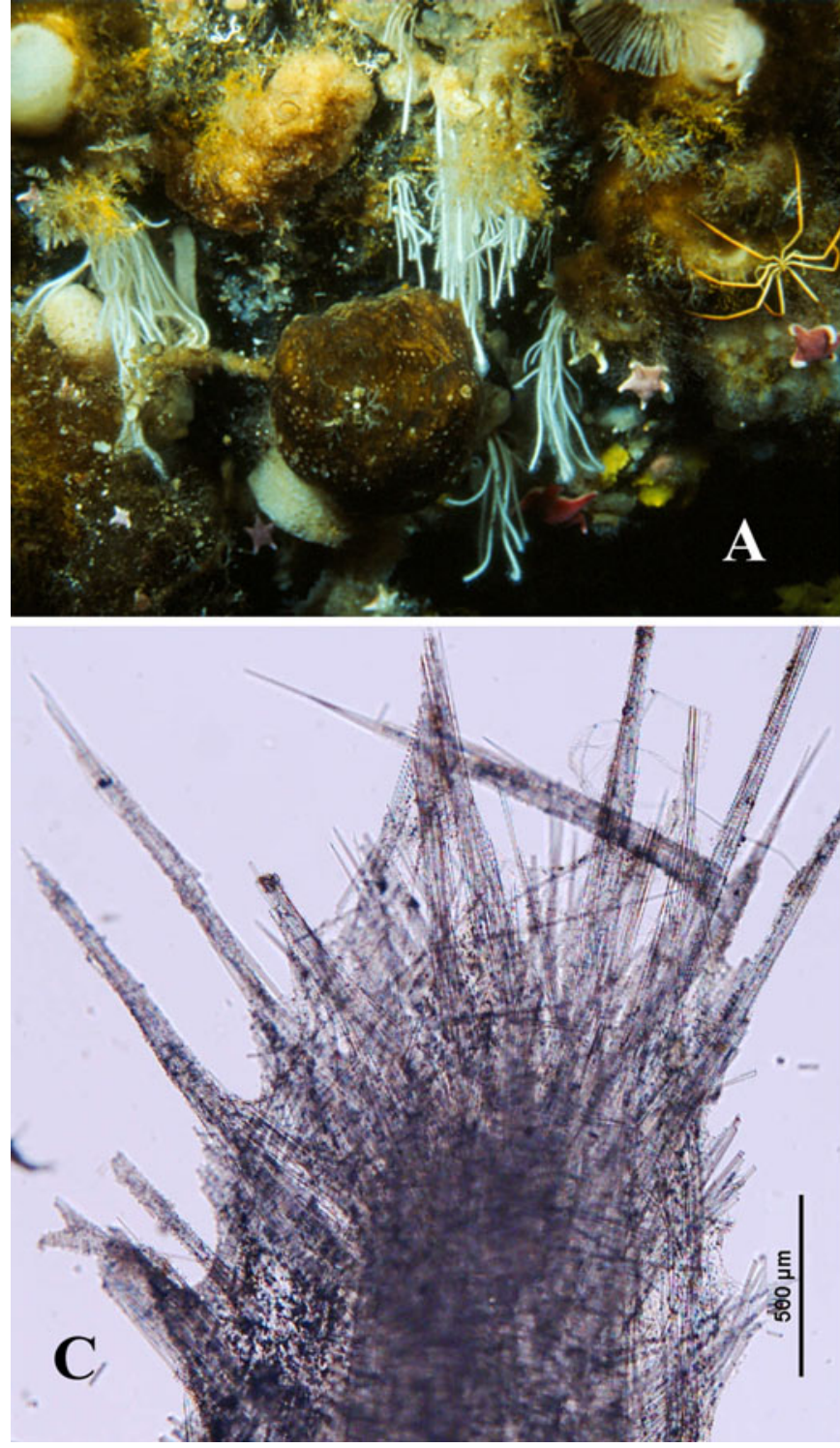

Fig. 1 Asbestopluma (Asbestopluma) vaceleti n.sp. a Sponge in situ at Turtle Rock, McMurdo Sound, $30 \mathrm{~m}$ (photo, B. Baker), b holotype ZMA Por. 13264, habit, c ending of one of the holotype branches

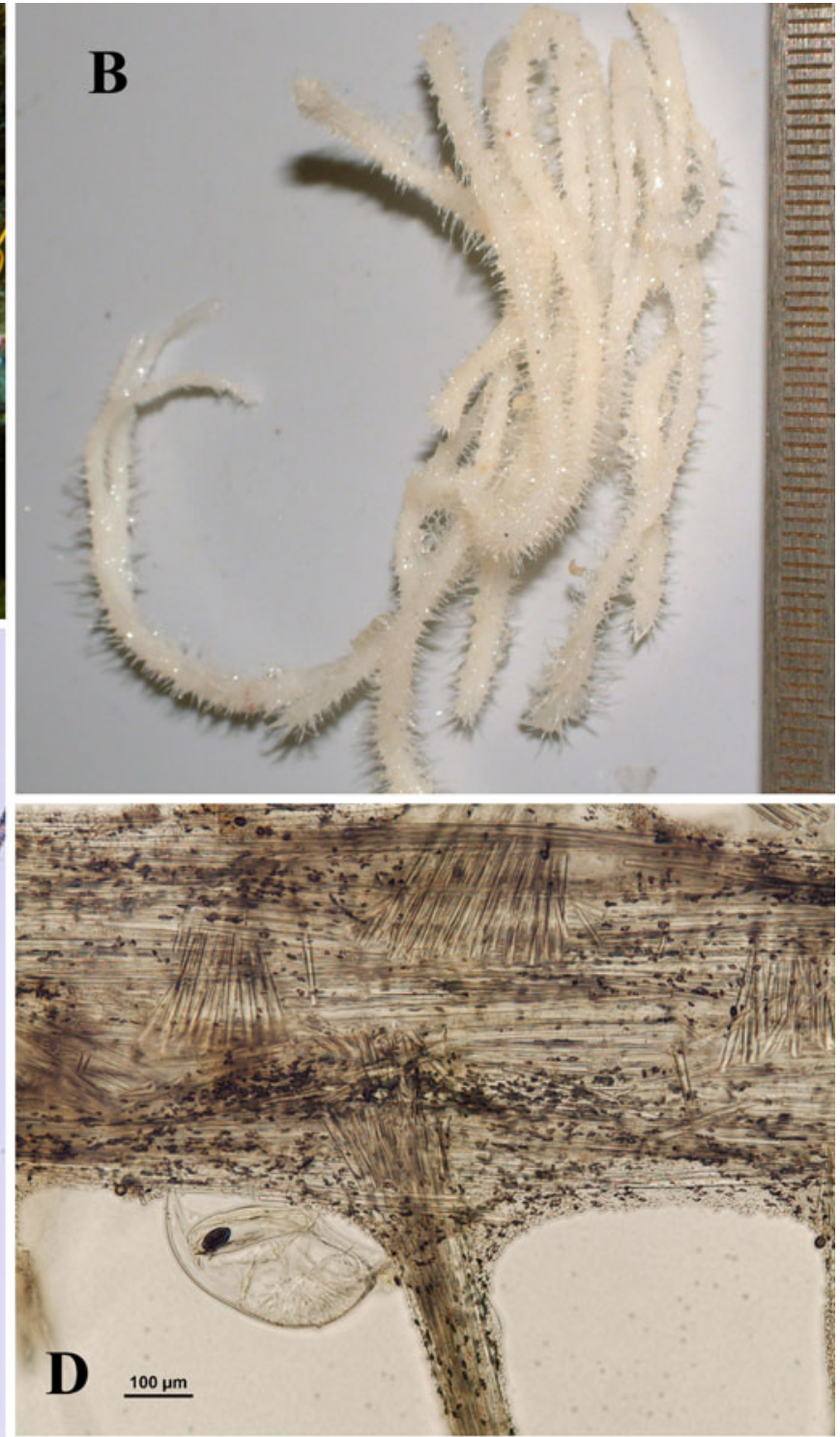

showing skeletal 'filaments' (scale bar $500 \mu \mathrm{m}$ ), d detail of surface showing trapped cladoceran (scale bar $100 \mu \mathrm{m}$ ) 
Fig. 2 Asbestopluma (Asbestopluma) vaceleti $\mathrm{n} . \mathrm{sp}$. Detail of branch ending and swollen apices of filaments of in situ specimen (photo, Shawn Harper)

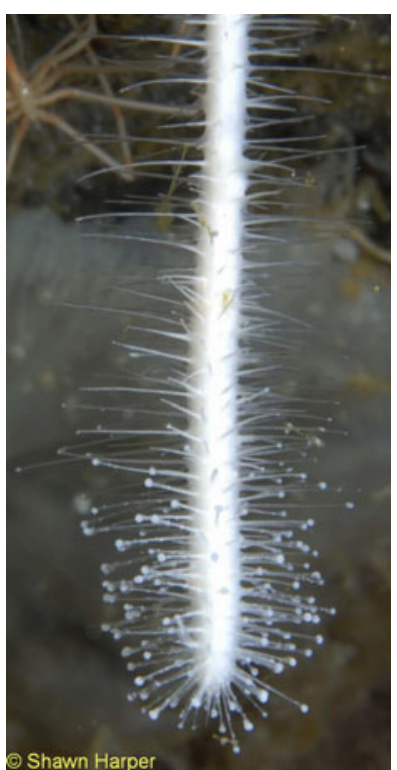

Skeleton (Figs 1c, d): long styles are arranged parallely in the centre of the stalks surrounded by tissue containing forcipes and chelae. At the surface, there is a dense lining of chelae. From the central axis at regular intervals, bundles of styles are sticking out at right angles forming the axis of the filaments (Fig. 1d). At the top of the stalk, the central axis fans out slightly and forms a dense bush of short spicule bundles sticking out beyond the surface (Fig. 1c).

The swollen endings of the terminal filaments (Fig. 2) have become shrunken in the preserved material to the extent that they are no longer clearly visible on the filaments. However, whereas most surfaces have a lining of anisochelae, we observed a slight amassing of anisochelae in distal parts of many of the filaments near the top of a branch. Conceivably, the swollen endings of the filaments were lined with anisochelae and, when they collapsed after the sponge was taken out of the water, they caused this increased amount of anisochelae near the end of the filaments.

Spicules Styles in two size classes, chelae in two shapes, forcipes.

Styles of the central axis (Fig. 3a), with narrow rounded heads and slightly swollen along the shaft ('fusiform styles'), length $\times$ width $1,210-1,408.2-1,645 \times 11-18.3-$ $30 \mu \mathrm{m}$.

Styles of the surface bundles (Fig. 3b), similar in shape but frequently with a faint tyle, 271-561.6-822 $\times 4-11.0$ $18 \mu \mathrm{m}$.

Forceps (Fig. 3c), arranged in rosette-like groups, legs often tangled or trailing to either side, legs provided with a terminal knob (Fig. 3d), 33-45.6-69 $\mu \mathrm{m}$.

Anisochelae in two shapes that were initially assumed to be growth stages of a single microsclere category. However, no real intermediates of the two types were found and their frequency of occurrence, though different, was high for both. Type 1 palmate anisochelae of the usual Asbestopluma type (Fig. 3e), with lateral upper alae entrely fused with the shaft, and with the lower alae serrated, of closely uniform size, 13-14.9-16 $\mu \mathrm{m}$. Type 2 sigma-like palmate anisochelae (Fig. 3f) with reduced upper alae and peculiar sharply chiseled lower alae, of closely similar size and shape, slightly smaller than the normal chelae, 12-12.8$14.5 \mu \mathrm{m}$.

Ecology Occurring in semi-open overhangs among densely crowded hard substrate communities at shallow depth $(30 \mathrm{~m})$. This is one of the carnivorous sponges sequestering small crustaceans (see Fig. 1d) from the ambient water by the sticky fringed surface. There are two photos of live individuals on the Scripps Ross Island and McMurdo Sound website (Brueggeman 1998), which are here reproduced in Fig. 1a and Fig.2. 


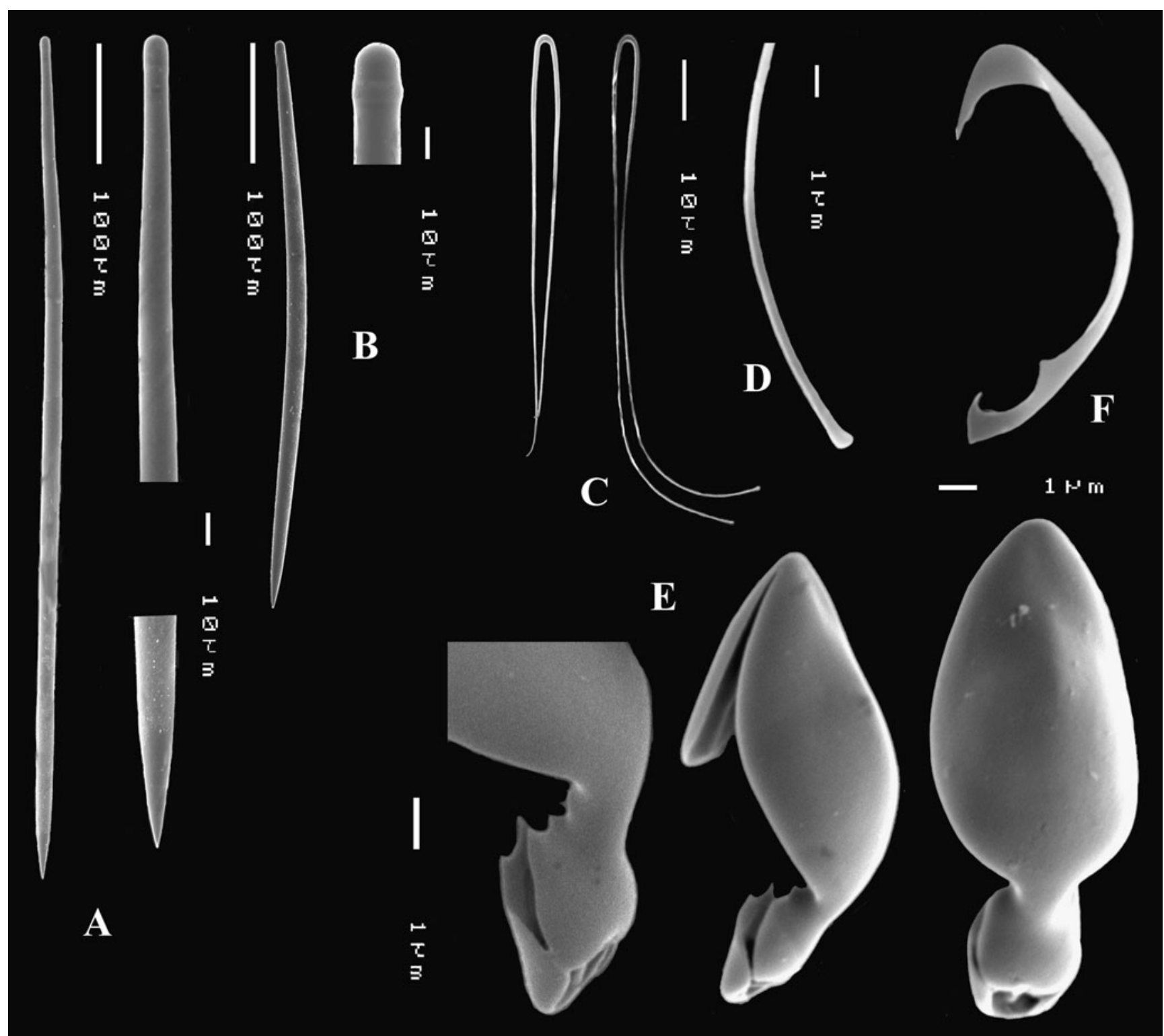

Fig. 3 Asbestopluma (Asbestopluma) vaceleti n.sp. a Style of the central axis, and details of apices, $\mathbf{b}$ style of the surface bundles and detail of tyled head, $\mathbf{c}$ forceps with straight and trailing legs, $\mathbf{d}$ detail of swollen end of forceps leg, e anisochelae 1 from side and back, and detail of serrated lower ala, $\mathbf{f}$ sigma-like anisochela 2

with sperm productions (Vacelet and Boury-Esnault 1996), so it could be speculated that-although unlikely - they may have been overlooked in previously reported Antarctic Asbestopluma species.

Table 1 lists all the reported Asbestopluma species from the Antarctic region. A. callitrix Hentschel (1914) is the only species that appears overall close. The habit is clubshaped with a smooth stalk but the ovoid 'body' appears somewhat similar to our new species although relatively much more swollen. The megascleres are up to $4 \mathrm{~mm}$ long, much longer than those of $A$. (A.) vaceleti $\mathrm{n}$.sp. and the chelae are only $11-12.5 \mu \mathrm{m}$. No forceps are reported and depth occurrence is $350-385 \mathrm{~m}$. A. calyx Hentschel (1914) 
Table 1 Spicule data of Antarctic Asbestopluma specimens

\begin{tabular}{|c|c|c|c|c|c|}
\hline Species & Long styles & Small styles & Anisochelae & Other & Depth \\
\hline $\begin{array}{l}\text { Asbestopluma n.sp.; } \\
\text { tangled branches }\end{array}$ & $1,210-1,645 \times 11-30$ & $217-822 \times 4-18$ & $\begin{array}{l}\text { (1) } 13-16 \\
\text { (2) Reduced } \\
12-14.5\end{array}$ & Forceps 33-69 & 30 \\
\hline $\begin{array}{l}\text { A. belgicae } \\
\text { Topsent } 1901 ; \\
\text { tangled branches }\end{array}$ & $800-1,400 \times 12-28$ & $250 \times 10-12$ & $10-12$ & $\begin{array}{l}\text { (1) Sigmas 27-33 } \\
\text { (2) Microtylostyles } \\
200 \times 2.5-3\end{array}$ & $370-569$ \\
\hline $\begin{array}{l}\text { A. callitrix } \\
\text { Hentschel 1914; } \\
\text { club-shaped }\end{array}$ & $4,000 \times 16$ & $400 \times 16$ & $11-13$ & - & $350-385$ \\
\hline $\begin{array}{l}\text { A. calyx } \\
\text { Hentschel 1914; } \\
\text { stalked cup }\end{array}$ & $456-600 \times 8-9$ & $200-390 \times 6$ & $14-21$ & - & $46-540$ \\
\hline $\begin{array}{l}\text { A. obae Koltun 1964; } \\
\text { single stalk }\end{array}$ & $1,100-1,750$ & $330-650$ & 10 & $\begin{array}{l}\text { (1) Sigmas 23-25 } \\
\text { (2) Microstyles } \\
85-170\end{array}$ & 2,250 \\
\hline $\begin{array}{l}\text { Asbestopluma sp. } \\
\text { Koltun } 1964\end{array}$ & $1,600-2,900 \times 20-32$ & $580-1,500 \times 10-16$ & $14-17$ & - & 4,350 \\
\hline
\end{tabular}

is a stalked cup and differs in having smaller styles and larger anisochelae. Likewise no forceps are mentioned and depth occurrence is bathyal. A. belgicae (Topsent 1901) is similar in habit to $A$. (A.) vaceleti $\mathrm{n}$.sp. forming long stalks with filaments along the entire stalk, but filaments are distinctly longer $(13 \mathrm{~mm})$ and more entangled than those of
A. vaceleti n.sp. Spiculation differs sharply by the possession of rugose microtylostyles and sigmas and depth occurrence is bathyal. A. obae Koltun (1966) is in most aspects similar to $A$. belgicae, but it apparently lacks filaments (fragmentary specimen). A further unnamed specimen reported from abyssal depth by Koltun (1966)

Table 2 Spicule data of Asbestopluma species possessing forceps microscleres

\begin{tabular}{|c|c|c|c|c|c|}
\hline Species & Long styles & $\begin{array}{l}\text { Small (tylo) } \\
\text { styles }\end{array}$ & Anisochelae & Forcipes & Distribution \\
\hline A. vaceleti $\mathrm{n} . \mathrm{sp}$.; tangled stalks & $1,210-1,645 \times 11-30$ & $217-822 \times 4-18$ & $\begin{array}{l}\text { (1) } 13-16 \\
\text { (2) Reduced } \\
12-14.5\end{array}$ & $33-69$ & Antarctic \\
\hline $\begin{array}{l}\text { A. cupressiformis } \\
\text { (Carter 1874; Lundbeck 1905); } \\
\text { stalk with elongate swelling }\end{array}$ & $500-900 \times 8-14$ & $350-500 \times 8-14$ & $23-25$ & $38-48$ & North Atlantic \\
\hline $\begin{array}{l}\text { A. lycopodium (Levinsen 1887); } \\
\text { tangled stalks }\end{array}$ & $600-1,500 \times 7-21$ & $238-600 \times 7-21$ & $14-17$ & $50-56$ & North Atlantic \\
\hline $\begin{array}{l}\text { A. lycopodium present study; } \\
\text { tangled stalks }\end{array}$ & $640-1,410 \times 6$ & $270 \times 8$ & $9-11$ & $18-32$ & $\begin{array}{l}\text { Rockall Bank, } \\
\text { North Atlantic }\end{array}$ \\
\hline $\begin{array}{l}\text { A. infundibulum (Levinsen 1887); } \\
\text { stalked fans/cups }\end{array}$ & $300-830 \times 5-11$ & $\begin{array}{l}\text { (1) } 170-300 \times 5-11 \\
\text { (2) } 149-220 \times 6\end{array}$ & $18-27$ & 75 & North Atlantic \\
\hline $\begin{array}{l}\text { A. infundibulum sensu } \\
\text { Boury-E. et al. 1994; } \\
\text { stalked fans/cups }\end{array}$ & $1,034 \times 12$ & $\begin{array}{l}\text { (1) } 168 \times 1 \\
\text { (2) } 60-85 \times 2-6\end{array}$ & $14-25$ & $42-48$ & Gulf of Cadiz \\
\hline $\begin{array}{l}\text { A. occidentalis (Lambe 1893); } \\
\text { tangled stalks }\end{array}$ & 1,390 & $410-680$ & 13 & 32 & NE Pacific \\
\hline $\begin{array}{l}\text { A. occidentalis sensu Koltun 1955; } \\
\text { fringed stalk }\end{array}$ & 700 & 100 & 10 & 25 & NW Pacific \\
\hline $\begin{array}{l}\text { A. versatilis (Topsent 1892); } \\
\text { stalk and ovoid body }\end{array}$ & 580 & - & 27 & 76 & North Atlantic \\
\hline $\begin{array}{l}\text { A. gracilis Koltun } 1955 \text {; } \\
\text { stalk with elongate swelling }\end{array}$ & 1,200 & 140 & 14 & 27 & NW Pacific \\
\hline $\begin{array}{l}\text { A. hadalis Lévi 1964; } \\
\text { stalk swollen midway }\end{array}$ & $1,500-3,200 \times 25-35$ & $700-850 \times 20-22$ & $14-16$ & $65-75$ & Kermadec Trench \\
\hline $\begin{array}{l}\text { A. hypogea Vacelet \& Boury-E. 1996; } \\
\text { stalk \& ovoid body }\end{array}$ & $350-920 \times 2-7$ & $385-780 \times 3-7$ & $9-13$ & $25-34$ & Mediterranean \\
\hline
\end{tabular}


has indistinct habit and clearly larger megascleres than $A$. (A.) vaceleti $\mathrm{n} . \mathrm{sp}$.

Originally, this species was provisionally identified as $A$. lycopodium Levinsen (1887) because of overall similarity with this Arctic-Boreal deep sea species. Probably as a result of a misspelling, this identification was changed to Asbestopluma aff. lycopodina Lundbeck (1905) in Brueggeman (1998), an incorrect name because the subgenus Lycopodina was erected by Lundbeck for a group of similar species including A. lycopodium, but there is no species named lycopodina. We were able to compare the present material with a small fragmentary specimen, ZMA Por. 19989, identified as A. lycopodium from Rockall Bank deep sea coral reefs, W of Ireland (Van Soest et al. 2007). The two are similar in habit and megasclere spiculation (see Table 2), but A. lycopodium lacks a second shape category of anisochelae and the microsclere sizes were clearly different (smaller forcipes and chelae). The latter difference may not be significant, as microsclere sizes for this species provided in the literature are different again from both the Antarctic and the Rockall Bank specimens. In fact, A. lycopodium is probably not the most similar Asbestopluma to our new species. The shallow water Mediterranean A. hypogea Vacelet and Boury-Esnault (1996) conforms to our new species in almost all aspects, but it has a smooth stalk and ovoid body, unlike $A$. (A.) vaceleti n.sp., smaller megascleres, smaller forcipes not arranged in rosettes, and the second category of reduced anisochelae is lacking.

From Table 2, it can be concluded that forceps microscleres occur so far almost exclusively in the northern hemisphere. An exception is A. hadalis Lévi (1964) from the Kermadec Trench. This differs from our new species in shape (swollen body midway in the stalk) and by having much larger long styles (up to 3,200 $\mu \mathrm{m}$ ). Furthermore, Janussen and Plotkin (personal communication, not mentioned in Table 2) collected a possibly new species of Asbestopluma from the deep Weddell Sea (c. $4400 \mathrm{~m}$ depth), which has unusually thick forceps and anisochelae clearly different in shape from those of $A$. (A.) vaceleti n.sp.

\section{Discussion}

The shallow-water occurrence of our new species parallels that of the Mediterranean A. hypogea, but there is one clear difference: A. hypogea occurs in a 'displaced deep sea' environment, comparable in trophic aspects to a true deep sea environment, whereas $A$. (A.) vaceleti $\mathrm{n} . \mathrm{sp}$. was found in a densely populated habitat with all the characteristics of high nutrient content (see Fig. 1a). Nevertheless, from indirect indications, it is likely that $A$. (A.) vaceleti $\mathrm{n} . \mathrm{sp}$. still maintains its carnivorous feeding strategy of being sticky and absorbing small invertebrates (see cladoceran fixed to the surface of the sponge in Fig. 1d). If this is corroborated by more direct observations, then we must assume that the carnivorous life strategy is firmly established in Asbestopluma, as it is maintained in $A$. (A.) vaceleti n.sp. even though a suspension feeding strategy would be more warranted in its habitat. The carnivorous feeding strategy occurring in shallow-water habitats represents a form of niche partitioning with a distinct advantage towards others members of the sessile community.

Acknowledgments A grant from the US National Science Foundation's Office of Polar Programs (OPP-9526610) facilitated collection of the sponge material and is gratefully acknowledged. Mr Shawn Harper (USAP Scientific Diver) allowed us to use Fig. 2 to illustrate the new species. Elly Beglinger (ZMA) assisted in making the SEM and light microscopy illustrations.

Open Access This article is distributed under the terms of the Creative Commons Attribution Noncommercial License which permits any noncommercial use, distribution, and reproduction in any medium, provided the original author(s) and source are credited.

\section{References}

Boury-Esnault N, Pansini M, Uriz MJ (1994) Spongiaires bathyaux de la mer d'Alboran et du golfe ibéro-marocain. Mem Mus Natl Hist Nat 160:1-174

Brueggeman P (1998) Underwater field guide to Ross Island and McMurdo Sound, Antarctica. Scripps Institution of Oceanography Library, UC San Diego, USA. Available online at http://escholarship. org/uc/item/6rt8r68s. Accessed 1 June 2010

Carter HJ (1874) Descriptions and figures of deep-sea sponges and their spicules from the Atlantic Ocean, dredged up on board $\mathrm{H}$. M.S.'Porcupine', chiefly in 1869; with figures and descriptions of some remarkable spicules from the Agulhas Shoal and Colon, Panama. Ann Mag Nat Hist 14:207-221, 245-257

Hentschel E (1914) Monaxone Kieselschwämme und Hornschwämme der Deutschen Südpolar-Expedition 1901-1903. Deutsche SüdpolarExpedition, 1901-03 15(1):35-141

Koltun VM (1955) [Sponges. In: Atlas of the Invertebrate Fauna of the Far-Eastern Seas of the USSR.] [In Russian] Akademiya Nauk SSSR, pp 45-50

Koltun VM (1964) Sponges of the Antarctic. 1 Tetraxonida and Cornacuspongida. In: Pavlovskii EP, Andriyashev AP, Ushakov PV (eds) Biological reports of the Soviet Antarctic Expedition (1955-1958), Akademya Nauk SSSR [English translation (1966), Israel Program for Scientific Translation], pp 6-133, $443-448$

Lambe LM ((1893) [1894]) Sponges from the Pacific coast of Canada. Proc Trans R Soc Can 11(4):25-43

Lévi C (1964) Spongiaires des zones bathyale, abyssale et hadale. Galathea Report Scientific Results of The Danish Deep-Sea Expedition Round the World (1950-52) 7:63-112

Levinsen GMR (1887) Kara-Havets Svampe (Porifera). DijmphnaTogtets zoologisk-botaniske Udbytte 1:339-372

Lundbeck W (1905) Porifera. (Part II) Desmacidonidae (pars). The Danish Ingolf-Expedition 6(2):1-219

Thomson CW (1873) The Depths of the Sea. Macmillan. London

Topsent E (1892) Contribution à l'étude des Spongiaires de l'Atlantique Nord (Golfe de Gascogne, Terre-Neuve, Açores). 
Résultats des campagnes scientifiques accomplies par le Prince Albert I Monaco 2:1-165

Topsent E (1901) Spongiaires. Résultats du voyage du S.Y. 'Belgica'en 1897-99 sous le commandement de A. de Gerlache de Gomery. Expédition antarctique belge Zoologie 4:1-54

Topsent E (1929) Notes sur Helophloeina stylivarians n.g. n.sp., Mycaline à desmes des Canaries. Bull Inst Océanogr Monaco $533: 1-8$

Vacelet J (2006) New carnivorous sponges (Porifera, Poecilosclerida) collected from manned submersibles in the deep Pacific. Zool J Linn Soc 148:553-584

Vacelet J, Boury-Esnault N (1995) Carnivorous sponges. Nature 373):333-335
Vacelet J, Boury-Esnault N (1996) A new species of carnivorous sponge (Demospongiae: Cladorhizidae) from a Mediterranean cave. In: Willenz P (ed) Recent Advances in Sponge Biodiversity Inventory and Documentation. Bull Inst R Sci Nat Belg Biol 66, pp 109-115

Van Soest RWM, Cleary DFR, De Kluijver MJ, Lavaleye MSS, Maier C, Van Duyl FC (2007) Sponge diversity and community composition in Irish bathyal coral reefs. Contrib Zool 76:121-142

Van Soest RWM, Boury-Esnault N, Hooper JNA, Rützler K, de Voogd NJ. Alvarez B, Hajdu E, Pisera AB, Vacelet J, Manconi R, Schönberg C, Janussen D, Tabachnick KR, Klautau M, Picton B (2008) World Porifera database. http://www.marinespecies.org/ porifera. Accessed 1 June 2010. 